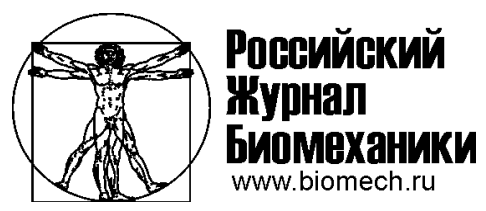

\title{
БИОМЕХАНИЧЕСКОЕ МОДЕЛИРОВАНИЕ ПРИМЕНЕНИЯ ШИНИРУЮЩЕГО ВОЛОКНА НА ОСНОВЕ БАЗАЛЬТА ПРИ ЛЕЧЕНИИ ПАЦИЕНТОВ С ЗАБОЛЕВАНИЯМИ ПАРОДОНТА
}

\author{
Е.М. Караваева ${ }^{1}$, Г.И. Рогожников ${ }^{1}$, Ю.И. Няшин ${ }^{2}$, В.Н. Никитин ${ }^{2}$ \\ ${ }^{1}$ Кафедра ортопедической стоматологии Пермского государственного медицинского университета \\ им. академика Е.А. Вагнера, Россия, 614990, Пермь, ул. Петропавловская, 26, e-mail: sortior@mail.ru \\ ${ }^{2}$ Кафедра теоретической механики и биомеханики Пермского национального исследовательского \\ политехнического университета, Россия, 614990, Пермь, Комсомольский проспект, 29, e-mail: \\ nyashin@inbox.ru, nikitinvladislav86@gmail.com
}

\begin{abstract}
Аннотация. Проблема заболеваний пародонта до настоящего времени остается в центре внимания многочисленных исследований и является актуальной в стоматологии. Это обусловлено широкой распространенностью (80-95 \%) заболеваний пародонта, сложностями диагностики в связи с многообразием клинических проявлений, трудностями лечения и профилактики. Одним из способов увеличения эфффективности лечения заболеваний пародонта является шинирование подвижных зубов (стягивание зубов крепкой тонкой проволокой). Применение биомеханического моделирования при планировании шинирования у данной группы пациентов позволит усовершенствовать существующие методы несъемного шинирования зубных рядов. Для этого с помощью пакета ANSYS авторами был произведен расчет напряжений, деформаций и перемещений, возникающих в волокне и зубах. Было исследовано два материала для шинирования: стекловолокно как наиболее используемый материал в существующей стоматологической практике и базальтовое волокно - новый для стоматологии материал, но имеющий лучшие физико-механические характеристики в сравнении со стекловолокном. В ходе биомеханического исследования выяснено, что величины интенсивностей напряжений в волокне не превышают допустимых значений предела прочности в обоих случаях, но запас прочности для случая базальтового волокна выше, чем при использовании стекловолокна. Решение задачи о возможности применения базальта как шинирующего материала является первым этапом в выборе диаметра волокна, места установки, количества зубов, участвующих при установке волокна, и количества волокон (количестве пазов) при учете поведения костной ткани нижней челюсти, твердых тканей зубов и периодонта под жевательной нагрузкой.
\end{abstract}

Ключевые слова: пародонт, шинирующее волокно, базальт, стекловолокно, зубы, подвижность.

\section{ВВЕДЕНИЕ}

Заболевания пародонта - одна из наиболее распространенных и сложных патологий челюстно-лицевой области $[1,5,6,9,11]$. По данным Всемирной

(С) Караваева Е.М., Рогожников Г.И., Няшин Ю.И., Никитин В.Н., 2015

Караваева Евгения Михайловна, ординатор кафедры ортопедической стоматологии, Пермь

Рогожников Геннадий Иванович, д.мед.н., профессор, заведующий кафедрой ортопедической стоматологии, Пермь

Няшин Юрий Иванович, д.т.н., профессор, научный руководитель кафедры теоретической механики и биомеханики, Пермь

Никитин Владислав Николаевич, старший преподаватель кафедры теоретической механики и биомеханики, Пермь 
организации здравоохранения (ВОЗ), функциональные расстройства зубочелюстной системы, обусловленные потерей зубов от заболеваний пародонта $[2,7]$, развиваются в пять раз чаще, чем при осложнениях кариеса.

Наиболее часто в практике врача-стоматолога встречаются воспалительные и дистрофические заболевания пародонта, такие как пародонтит и пародонтоз, которые имеют серьезное влияние на функционирование всей зубочелюстной системы.

Пародонтит - воспаление тканей пародонта, характеризующееся деструкцией связочного аппарата, периодонта и альвеолярной кости. Существуют три степени тяжести пародонтита, и определяются они в основном тремя ведущими симптомами глубиной пародонтального кармана, степенью резорбции костной ткани и, как следствие, подвижностью зубов. Эти признаки принимаются за основу при выборе хирургического и ортопедического лечения.

При пародонтите легкой степени глубина пародонтального кармана достигает 3,5 мм, преимущественно в области межзубного промежутка, отмечается начальная степень деструкции костной ткани межзубных перегородок (разволокнение или исчезновение замыкающих пластинок, явления остеопороза, незначительное снижение высоты межзубных перегородок - менее 1/3), индуцированная кровоточивость. При легкой степени пародонтита общее состояние больного обычно не нарушено.

Для пародонтита средней тяжести характерны увеличение глубины кармана до 5 мм, резорбция костной ткани межзубных перегородок от $1 / 3$ до $1 / 2$; патологическая подвижность зубов I-II степени, возможны смещения зубов, появление трем (больших промежутков между зубами), травматическая окклюзия.

Для пародонтита тяжелой степени клиническая симптоматика такова: пародонтальный карман больше 5-6 мм, II-III степень патологической подвижности зубов, резорбция костной ткани на величину более $1 / 2$ высоты межзубных перегородок, иногда полное рассасывание альвеолярной перегородки, смещение зубов, травматическая артикуляция, значительные тремы (большие расстояния между зубами), дефекты зубных рядов.

Парадонтоз - генерализованный, первично дистрофический процесс в тканях пародонта, в основе которого лежат системные нарушения трофики и микроциркуляции. Пародонтоз, как правило, является одним из симптомов системного остеопороза. При пародонтозе происходит медленная, равномерная ретракция десны, горизонтальная атрофия костной ткани альвеолярного отростка, и, как следствие, развивается патологическая подвижность зубов (рис. 1).

Таким образом, патология пародонта практически всегда сопровождается патологической подвижностью зубов. Именно поэтому шинирование зубов является одним из этапов комплексного лечения заболеваний пародонта. Шинирование - это стягивание зубов крепкой тонкой проволокой, которая позволяет осуществить прочную горизонтальную связь между соседними зубами [3, 4, 12, 13, 15, 17, 19, 20, 21].

Одним из самых популярных материалов для шинирования является стекловолокно. Но при этом такие шины имеют ряд недостатков, например, разволокнение при разрезании или моделировке, трудная адаптация к зубам, сложность в работе [10]. Авторами предложен новый материал для шинирования, лишенный этих недостатков, - базальтовое волокно. Базальтовое волокно имеет хорошие физикомеханические характеристики, безопасно и удобно в работе. Для обоснования рациональности применения шины из базальтового волокна необходимо провести биомеханическое моделирование процесса шинирования и сравнить показатели напряжений и деформации для стекловолоконной и базальтовой шин.

Для моделирования процесса стоматологической помощи пациенту была выполнена конусно-лучевая компьютерная томография. На основании полученного снимка были определены анатомические размеры альвеолярного отростка, размеры 
зубов, их наклон и расстояние между зубами. В качестве объекта моделирования был выбран фронтальный участок нижней челюсти, так как именно в этой области зубы при заболеваниях пародонта чаще всего имеют патологическую подвижность. В процессе функционирования фронтальные зубы испытывают не только сжимающие, но и изгибающие нагрузки. Нагрузка на них приходится приблизительно под углом 20-30 по отношению к продольной оси зуба и составляет порядка 125-178 Н [16, 18$]$.

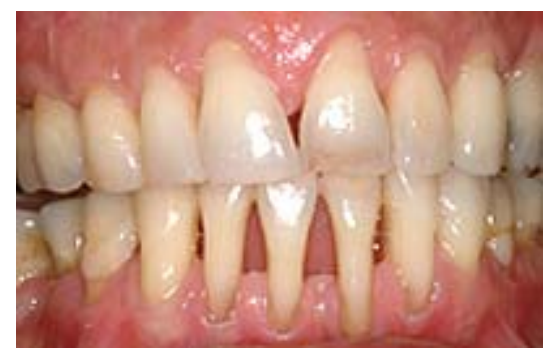

Рис. 1. Снижение десневого края передних зубов при пародонтозе

\section{МЕТОДИКА ОЦЕНКИ СОСТОЯНИЯ АЛЬВЕОЛЯРНОГО ОТРОСТКА}

На рис. 2 приведены результаты трехмерной дентальной компьютерной томографии, благодаря которым были получены следующие данные, приведенные в табл. 1 и на рис. 3.

Размеры передних зубов

Таблииа 1

\begin{tabular}{|c|c|c|c|c|c|c|}
\hline \multirow{2}{*}{ Параметр } & \multicolumn{5}{|c|}{ 3уб } \\
\cline { 2 - 8 } & 43 & 42 & 41 & 31 & 32 & 33 \\
\hline $\begin{array}{c}\text { Ширина на сагиттальной плоскости } \\
\text { (самое широкое мест), мм }\end{array}$ & 6,5 & 7 & 6 & 6 & 6 & 6,5 \\
\hline $\begin{array}{c}\text { Ширина на корональной плоскости } \\
\text { (самое широкое место), мм }\end{array}$ & 6,3 & 4,9 & 4,2 & 5 & 4,2 & 6,5 \\
\hline Длина, мм & 18 & 17 & 21 & 20,5 & 22 & 17 \\
\hline
\end{tabular}

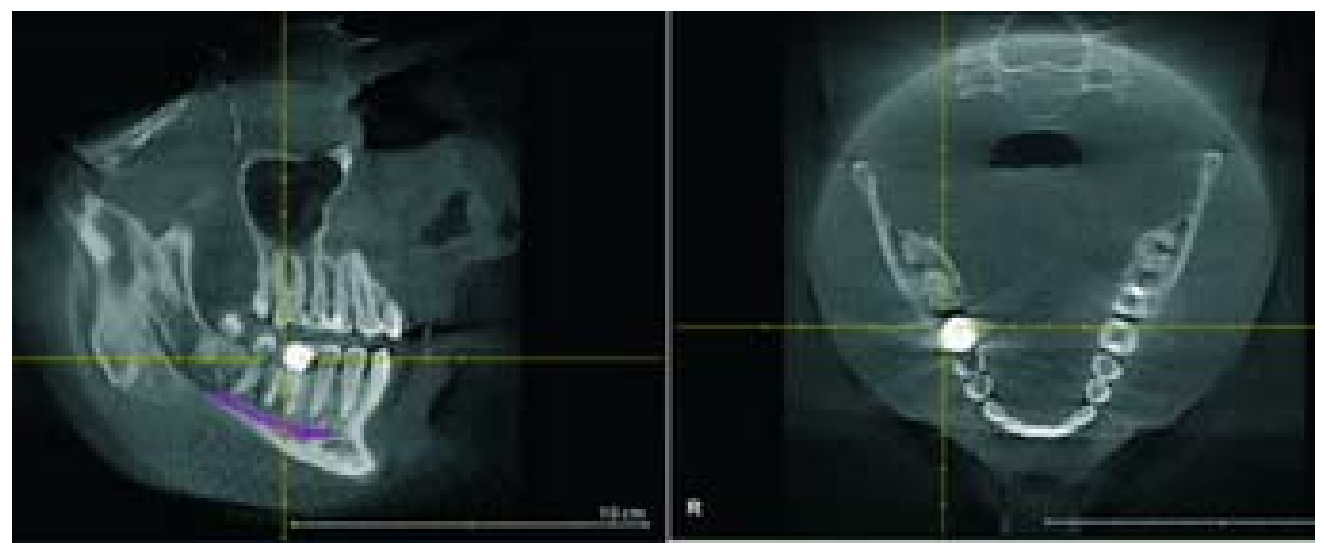

Рис. 2. Трехмерная дентальная компьютерная томография 


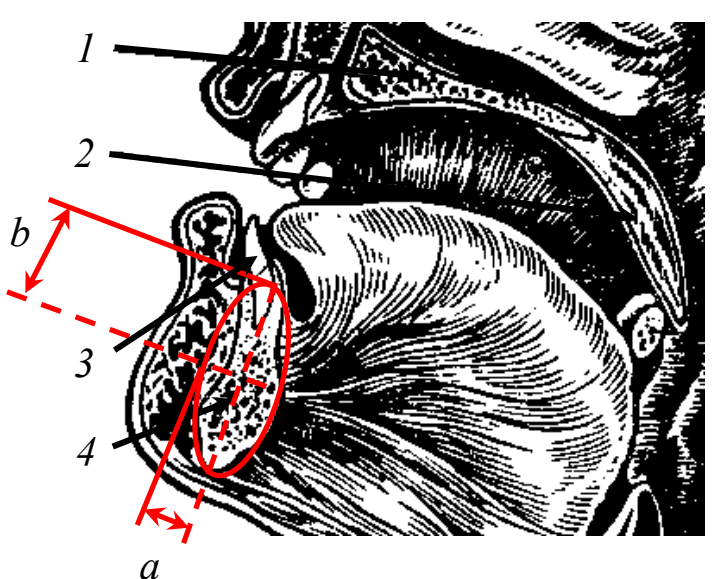

Рис. 3. Аппроксимация поперечного сечения тела нижней челюсти как эллипса [8]: 1 - твердое небо; 2 - мягкое небо; 3 центральный резец нижней челюсти; 4 - нижняя челюсть

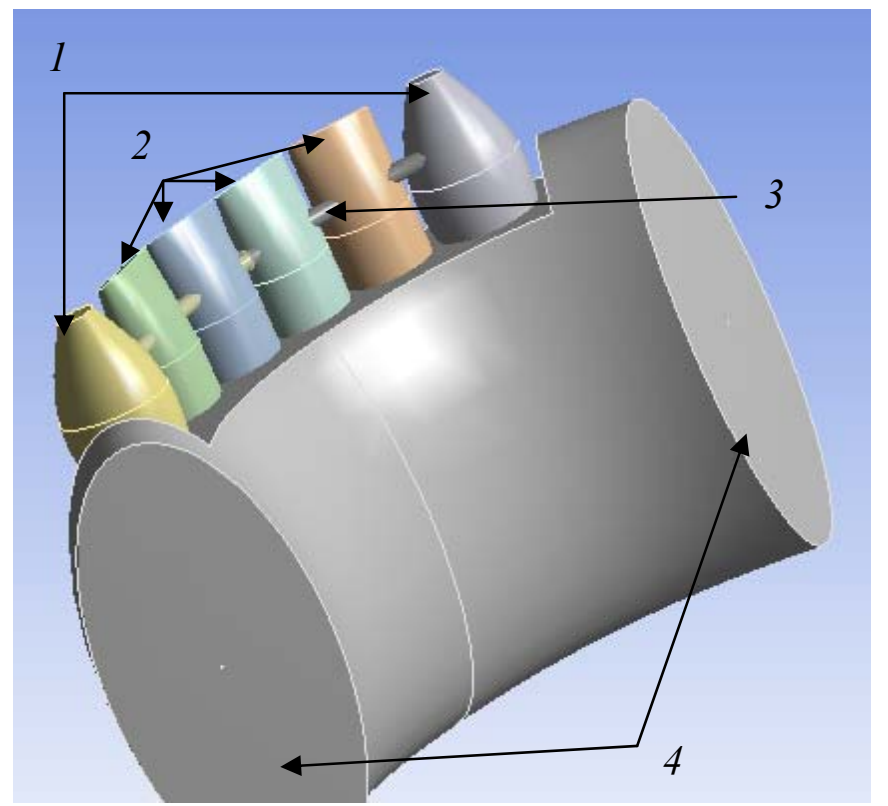

Рис. 4. Модель шинирования зубов: 1 - клыки; 2 - резцы; 3 - волокно; 4 - нижняя челюсть

В качестве модели была взята область, представленная на рис. 4. Эта модель в первом приближении описывает геометрию области нижней челюсти ( $a=5$ мм и $b=12,5$ мм), в которой расположены фронтальные зубы: резцы и клыки.

\section{БИОМЕХАНИЧЕСКИЙ РАСЧЕТ ШИНИРУЮЩЕГО ВОЛОКНА}

Пусть исследуемое тело, состоящее из тела нижней челюсти, зубов (резцы и клыки) и шинирующего волокна диаметром 1 мм, погруженного в зубы, занимает ограниченную область $\Omega$ трехмерного евклидова пространства $E^{3}$. Замыкание области обозначим через $\bar{\Omega}$, границу - через $\Gamma(\bar{\Omega}=\Omega \cup \Gamma)$ (рис. 5).

Рассмотрим нагружение шинированных зубов жевательной силой $P=100 \mathrm{H}$, распределенной по поверхности четырех нижних передних резцов, которая соответствует силе при смыкании челюстей на резцы и приложена под углом $20^{\circ}$ 
к продольной оси зубов. Будем определять напряжения, возникающие в зубах и волокне, и сравнивать их с предельными значениями для выяснения возможности применения волокна из базальта и стекловолокна в качестве шинирующего элемента.

Запишем систему уравнений, описывающих механическое поведение шинированных зубов в нижней челюсти при жевательной нагрузке.

1. Уравнение статического равновесия внутри области

$$
\operatorname{Div} \tilde{\sigma}=0, \quad \vec{r} \in \Omega,
$$

где $\widetilde{\sigma}$ - симметричный тензор напряжений. В формуле (1) и далее величины $\widetilde{\sigma}, \widetilde{\varepsilon}, \vec{u}$ считаются функциями координат, представленными радиусом-вектором $\vec{r} \in \bar{\Omega}$.

2. Упругие деформации связаны с напряжениями законом Гука

$$
\tilde{\sigma}=\tilde{\tilde{C}} \cdot \tilde{\varepsilon}, \vec{r} \in \bar{\Omega},
$$

где $\tilde{\tilde{C}}$ - четырехвалентный тензор модулей упругости, $C_{i j k l} \in C^{1}(\bar{\Omega})$.

3. Геометрические соотношения Коши

$$
\tilde{\varepsilon}=\frac{1}{2}(\vec{\nabla} \vec{u}+\vec{u} \vec{\nabla}), \quad \vec{r} \in \bar{\Omega},
$$

где $\vec{u}$ - вектор перемещения, $\vec{u} \in\left(C^{2}(\bar{\Omega})\right)^{3}$.

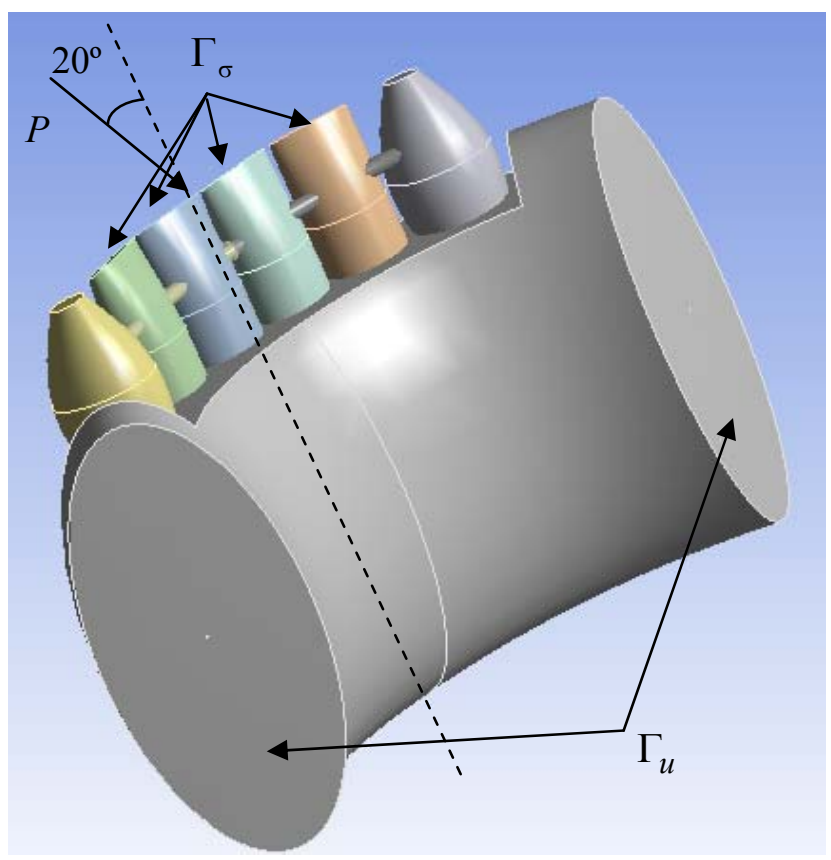

Рис. 5. Постановка задачи нагружения нижней челюсти, зубов и волокна

Таблица 2

Механические свойства зубов, костной ткани нижней челюсти, базальта и стекловолокна

\begin{tabular}{|c|c|c|c|c|}
\hline \multirow{2}{*}{ Параметр } & \multicolumn{4}{|c|}{ Материал } \\
\cline { 2 - 5 } & Зубы & $\begin{array}{c}\text { Костная ткань } \\
\text { нижней челюсти }\end{array}$ & Базальт & Стекловолокно \\
\hline Модуль Юнга $E$, ГПа & $1,8 \cdot 10^{4}$ & 10 & $87,1 \pm 2,3$ & $76,2 \pm 1,7$ \\
\hline Коэффициент Пуассона $v$ & 0,3 & 0,3 & 0,4 & 0,4 \\
\hline Предел прочности $\sigma_{\text {пр, МПа }}$ & 11,5 & 100 & $2245,3 \pm 126,8$ & $1547,7 \pm 155,9$ \\
\hline
\end{tabular}


4. Будем считать, что граница области $\Gamma$ делится на две взаимно непересекающиеся части $\Gamma=\Gamma_{u}+\Gamma_{\sigma}$. На части границы $\Gamma_{u}$ заданы кинематические граничные условия, на части $\Gamma_{\sigma}$ задан вектор силы $\vec{P} \in\left(C\left(\Gamma_{\sigma}\right)\right)^{3}$ :

$$
\begin{gathered}
\vec{u}=0, \quad \vec{r} \in \Gamma_{u}, \\
\vec{n} \cdot \tilde{\sigma}=\vec{P}, \quad \vec{r} \in \Gamma_{\sigma} .
\end{gathered}
$$

В табл. 2 приведены механические свойства зубов, костной ткани нижней челюсти, базальта и стекловолокна.

На рис. 6-13 представлены результаты биомеханического моделирования этой задачи в пакете ANSYS.

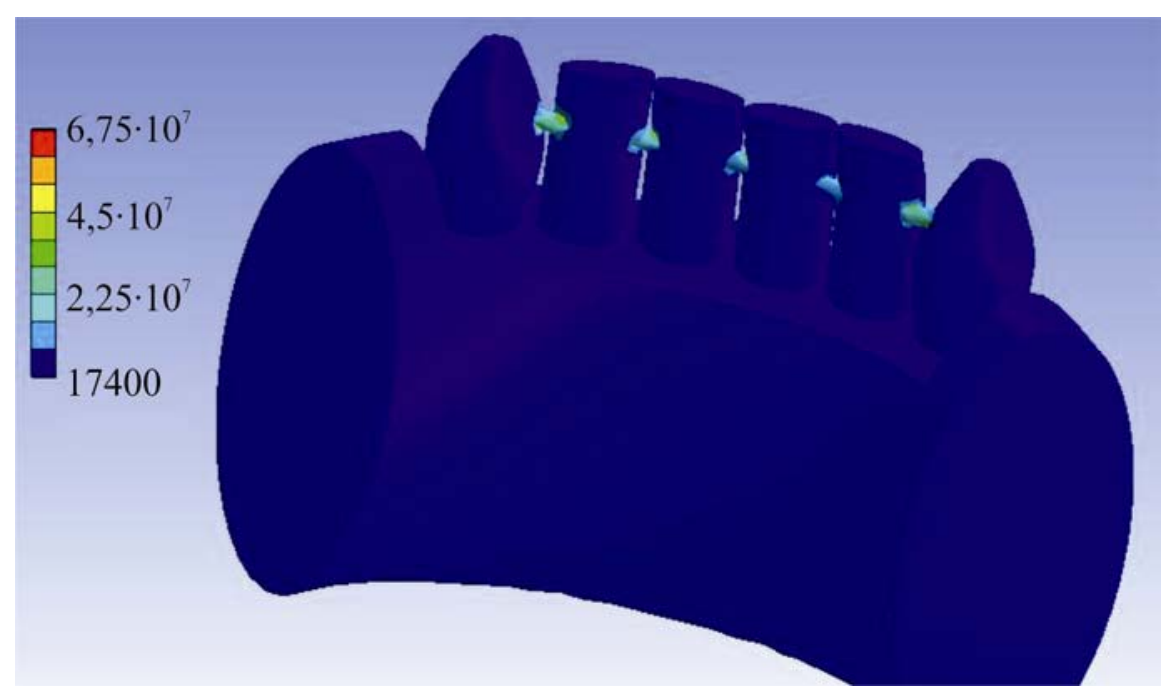

Рис. 6. Интенсивность напряжений по Мизесу в теле нижней челюсти, зубах и стекловолокне

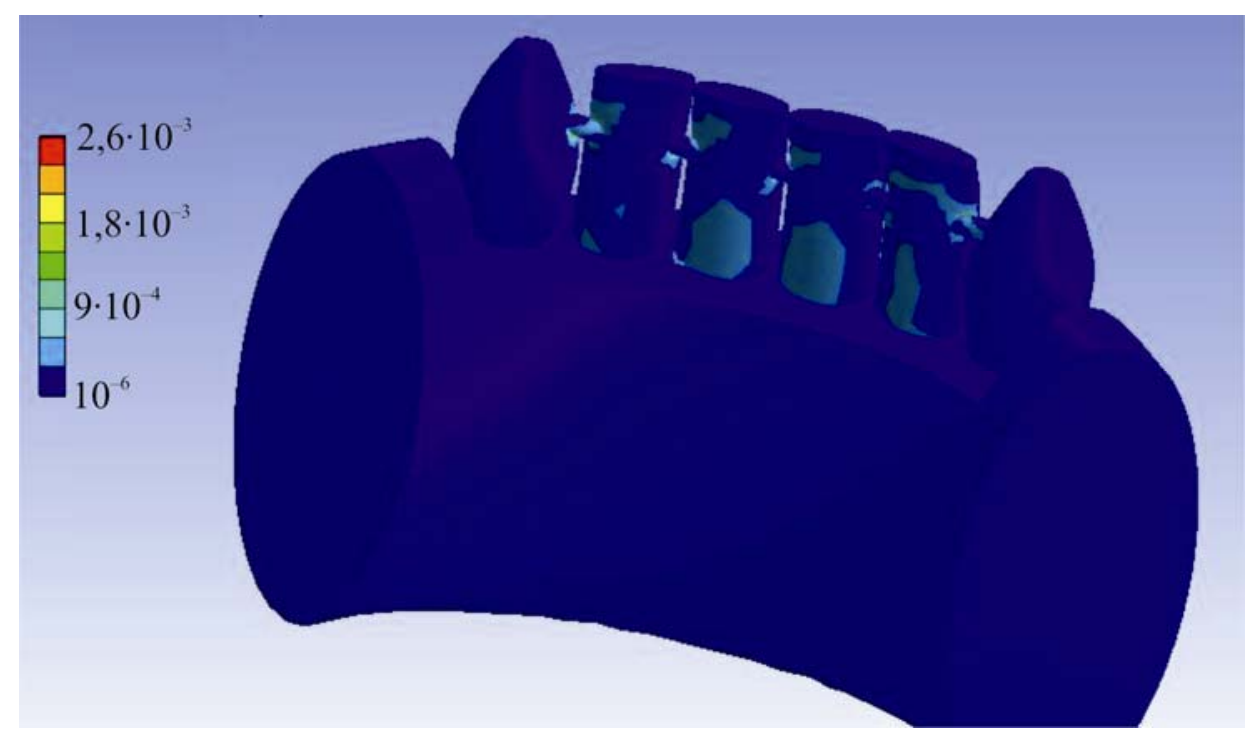

Рис. 7. Интенсивность деформаций по Мизесу в теле нижней челюсти, зубах и стекловолокне 


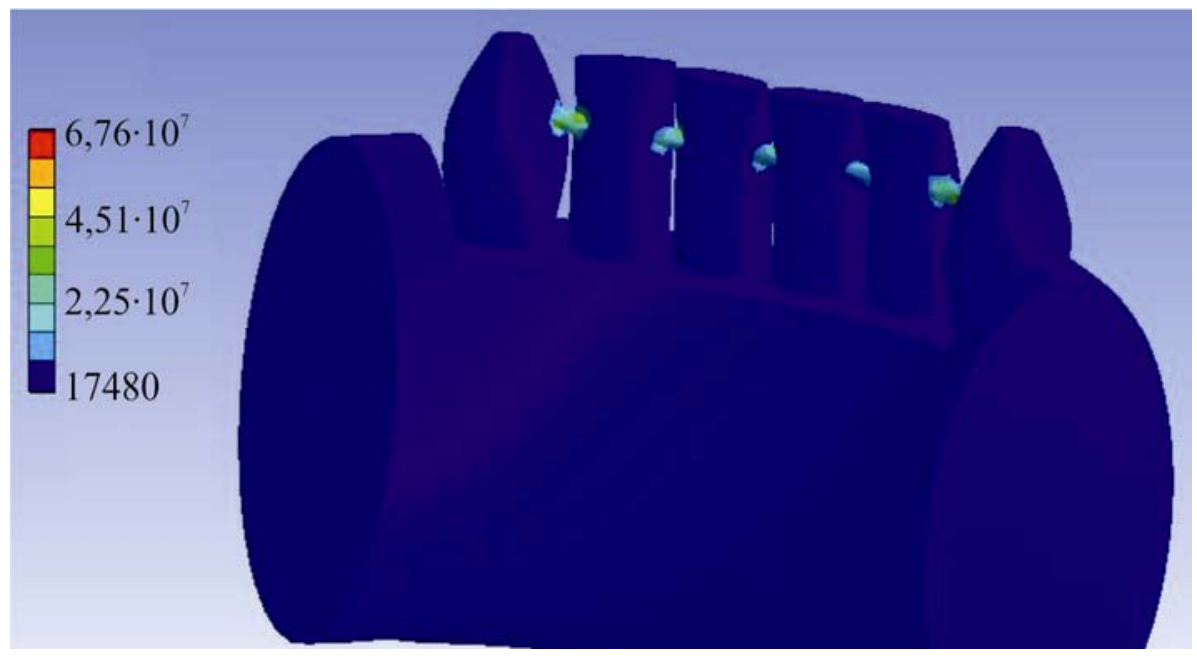

Рис. 8. Интенсивность напряжений по Мизесу в теле нижней челюсти, зубах и базальтовом волокне

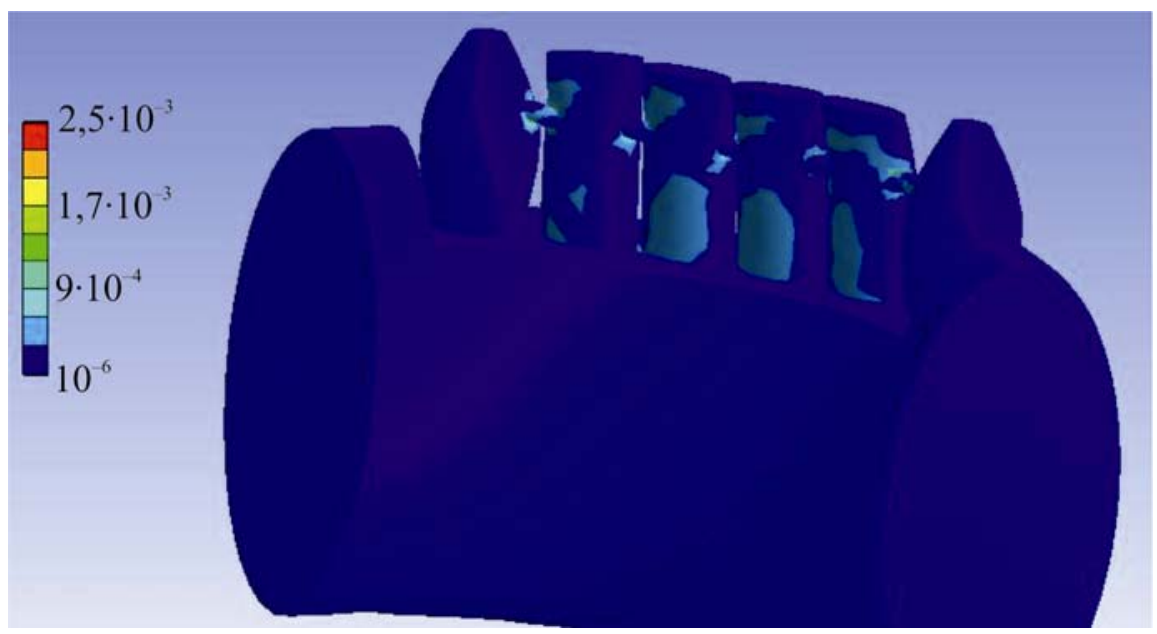

Рис. 9. Интенсивность деформаций по Мизесу в теле нижней челюсти, зубах и базальтовом волокне

По данным, представленным в табл. 3, видно, что использование шины из базальта по сравнению со стекловолокном незначительно увеличивает максимальные значения напряжений в волокне и зубах.

Использование базальтового волокна показало себя как эффективный метод снижения подвижности зубов и нагрузки на альвеолярный отросток нижней челюсти, являющейся опорной зоной зубов, вступивших в процесс жевания. Шинирующей

Таблица 3

Сравнение максимальных значений напряжений, деформаций и перемещений

\begin{tabular}{|c|c|c|c|}
\hline \multirow{2}{*}{ Значение } & \multicolumn{2}{|c|}{ Материал шинирующего волокна } & \multirow{2}{*}{ Изменение, \% } \\
\cline { 2 - 3 } & Стекловолокно & Базальт & \\
\hline Интенсивность напряжений, $10^{7}$ Па & 6,755 & 6,763 & $-0,1$ \\
\hline Интенсивность деформаций, $10^{-3}$ & 2,62 & 2,55 & $+2,7$ \\
\hline Горизонтальное перемещение, $10^{-5}$ м & 1,11 & 1,09 & $+1,8$ \\
\hline Вертикальное перемещение, $10^{-6}$ м & 3,5 & 3,45 & $+1,4$ \\
\hline
\end{tabular}




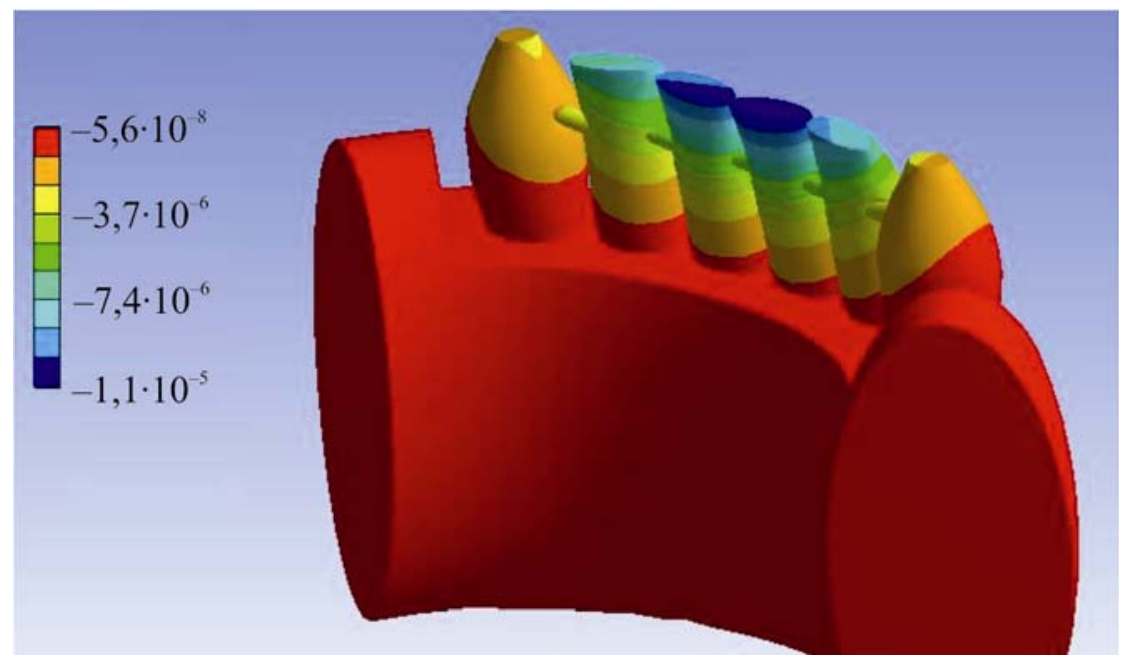

Рис. 10. Горизонтальное перемещение в теле нижней челюсти, зубах и стекловолокне

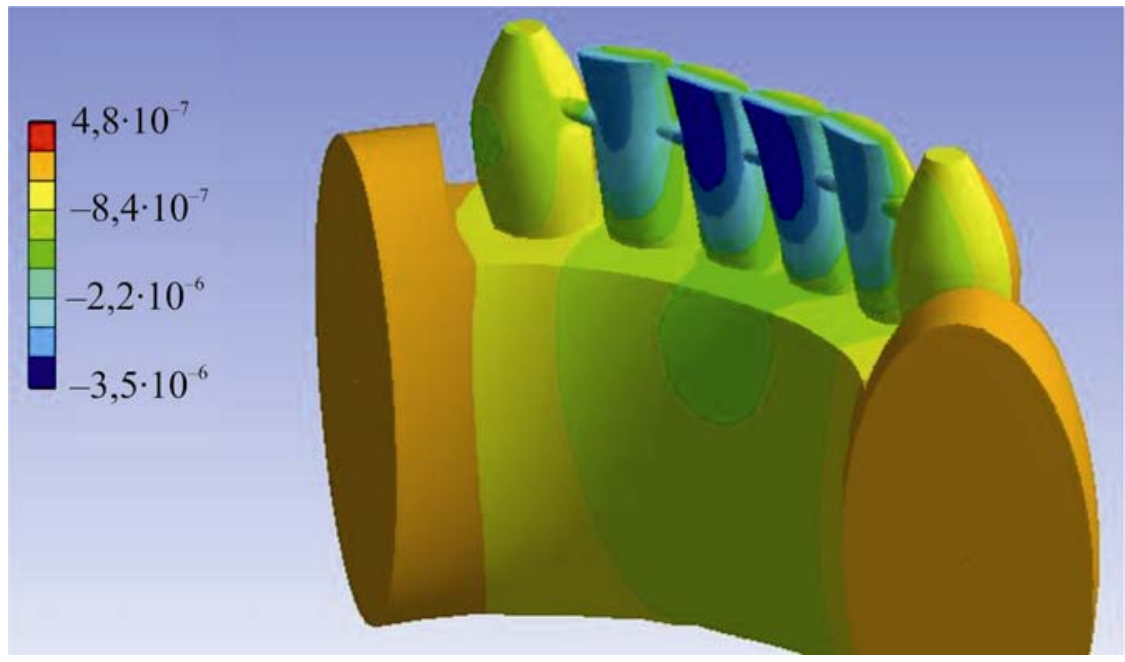

Рис. 11. Вертикальное перемещение в теле нижней челюсти, зубах и стекловолокне

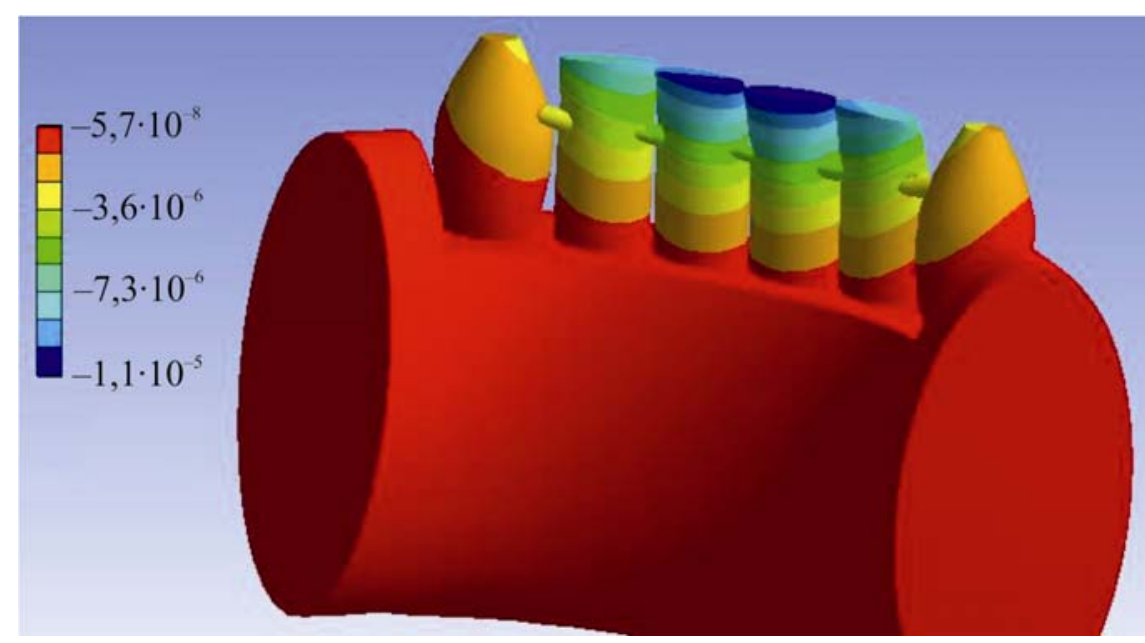

Рис. 12. Горизонтальное перемещение в теле нижней челюсти, зубах и базальтовом волокне

конструкции из базальтового волокна, закрепленной в пазе композиционным материалом с оральной стороны, оказалось достаточно, чтобы эффективно снизить подвижность зубов. Следовательно, базальт, который предложен авторами в качестве 


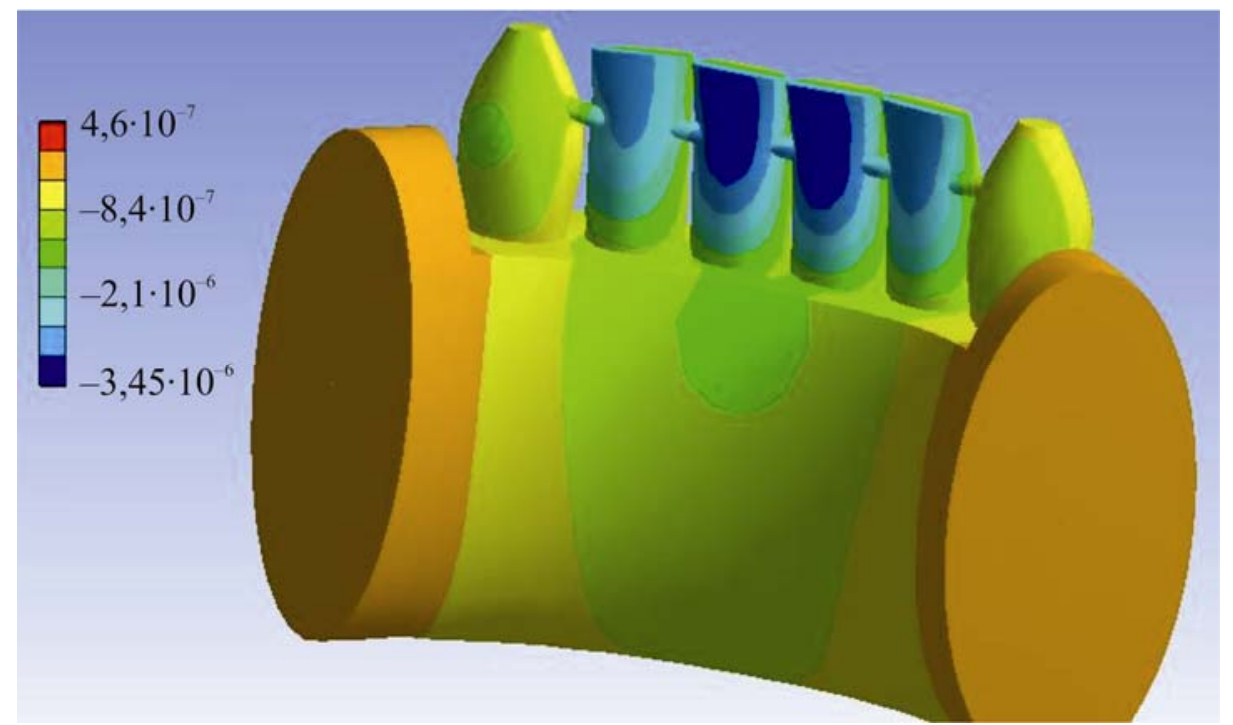

Рис. 13. Вертикальное перемещение в теле нижней челюсти, зубах и базальтовом волокне

материала шинирующего волокна, отвечает всем требованиям, предъявляемым к шинирующей конструкции, и может эффективно применяться для лечения заболеваний пародонта $[12,14,15]$.

\section{Выводы}

Сравнение напряженного деформированного состояния конструкции, состоящей из зубов, шинирующего волокна и кости тела нижней челюсти, при использовании базальтового волокна и стекловолокна показало, что величины интенсивностей напряжений в волокне не превышают допустимых значений предела прочности в обоих случаях. Это позволяет сказать, что базальтовое волокно можно применять в качестве шинирующего материала при пародонтите.

Решение данной задачи позволяет с помощью биомеханического моделирования дать количественные оценки существующей методике шинирования и дать рекомендации по ее уточнению на основе выбора диаметра применяемого волокна, места установки, количества зубов, участвующих при установке волокна, и количества волокон (количества пазов) при учете поведения костной ткани нижней челюсти, твердых тканей зубов и периодонта под жевательной нагрузкой $[8,12,14,17,20]$.

\section{СПИСОК ЛИТЕРАТУРЫ}

1. Гаражин Н.Н. Анатомия и гистология зубов человека. - Ставрополь, 1995.

2. Жулёв Е.Н. Клиника, диагностика и ортопедическое лечение заболеваний пародонта. - Н. Новгород: Изд-во НГМА, 2003.

3. Журавлев В.А., Казакова А.В. Методы фиксации подвижных зубов при лечении хронического генерализованного пародонтита // Проблемы стоматологии. - 2014. - № 2. - С. 4-8.

4. Кирюхин В.Ю., Рогожников Г.И., Мартюшева М.В., Гилязева Р.Ф. Об эффективности применения шинирования зубов жгутом из титановой нити при заболеваниях пародонта // Российский журнал биомеханики. - 2007. - Т. 11, № 2. - С. 65-74.

5. Копейкин В.Н. Ортопедическое лечение заболеваний пародонта. - М.: Триада-Х, 1998. - 176 с.

6. Котлер А.А., Куриленко В.С. Зубные протезы. - Киев: Здоровье, 1982.

7. Курякина Н.В., Кутепова Т.Ф. Заболевания пародонта. - М.: Медицинская книга; Н. Новгород: Издво НГМА, 2003.

8. Пекерская Е.М. Вокальный букварь. - М.: ТЦ Сфера, 1996. - 69 с.

9. Фурса В.Т. Болезни пародонта и их профилактика // Фельдшер и акушерка. - 1990. - № 4. - С. 25 -29.

10. Юдина Н.А., Азаренко В.И., Терехова Н.В. Временное шинирование в комплексном лечении болезней периодонта: учеб.-метод. пособие. - Мн.: БелМАПО, 2006. 
11. Baelum V., López R. Periodontal disease epidemiology - learned and unlearned? // Periodontol. - 2000. 2013. - Vol. 62, № 1. - P. 37-58.

12. Baruch H., Ehrlich J., Yaffe A. Splinting - a review of the literature // Refuat Hapeh Vehashinayim. 2001. - Vol. 18, № 1. - P. 29-40.

13. Barzilay I. Splinting teeth - a review of methodology and clinical case reports // J. Can. Dent. Assoc. 2000. - Vol. 66, № 8. - P. 440-443.

14. Bernal G., Carvajal J.C., Muñoz-Viveros C.A. A review of the clinical management of mobile teeth // J. Contemp. Dent. Pract. - 2002. - Vol. 3, № 4. - P. 10-22.

15. Forabosco A., Grandi T., Cotti B. The importance of splinting of teeth in the therapy of periodontitis // Minerva Stomatol. - 2006. - Vol. 55, № 3. - P. 87-97.

16. Linden R.W.A. The scientific basis of eating: taste and smell, salivation, mastication and swallowing, and their dysfunctions. - Basel: Karger Medical and Scientific Publishers, 1998. - 244 p.

17. Mosedale R.F. Current indications and methods of periodontal splinting // Dent. Update. - 2007. - Vol. 34, № 3. - P. 168-170.

18. Naini R.B., Nokar S., Borghei H., Alikhasi M. Tilted or parallel implant placement in the completely edentulous mandible? A three-dimensional finite element analysis // Int. J. Oral Maxillofac. Implants. 2011. - Vol. 26, № 4. - P. 776-781.

19. Nibali L., Farias B.C., Vajgel A., Tu Y.K., Donos N. Tooth loss in aggressive periodontitis: a systematic review // J. Dent. Res. - 2013. - Vol. 92, № 10. - P. 868-875.

20. Vályi P., Gorzó I. Current splinting methods in dentistry. I. // Fogorv. Sz. - 2003. - Vol. 96, № 1. P. 25-28.

21. Watkins S.J., Hemmings K.W. Periodontal splinting in general dental practice // Dent. Update. - 2000. Vol. 27, № 6. - P. 278-285.

\section{BIOMECHANICAL MODELLING OF APPLICATION OF SPLINTING FIBER ON THE BASIS OF BASALT IN THE TREATMENT OF PATIENTS WITH PARODONTAL DISEASES}

\section{E.M. Karavaeva, G.I. Rogozhnikov, Y.I. Nyashin, V.N. Nikitin (Perm, Russia)}

The problem of periodontal diseases still remains in the spotlight of numerous studies and is an actual problem in dentistry. This is due to high prevalence (80-95\%) of periodontal diseases, diagnostic difficulties for the variety of clinical manifestations, difficulties of treatment and prevention. One way of increasing of efficiency of the treatment of parodontal diseases is splinting of mobile teeth (tighting of teeth by strong thin wire). The application of biomechanical modelling in planning splinting in this group of patients would improve the existing methods of non-removable splinting of dentitions. For this purpose, stresses, deformations and displacements arising in the fiber and teeth are calculated using ANSYS package. Two splinting materials are studied: fiberglass (the most used material in the existing dental practice) and basalt fiber (new material for dentistry), which has better physical and mechanical properties compared with fiberglass. The magnitudes of the intensities of stresses in the fiber do not exceed the allowable strength limit values in both cases during biomechanical studies, but the safety factor for the case of basalt fiber is higher than at using of glass fiber. Solution of the problem of the possibility of applying of basalt as a splinting material is the first stage in choosing of the fiber diameter, the place of installation, the number of teeth participating during installation fiber, and the number of fibers (number of slots) taking into account the behavior of bone tissue of the mandible, hard tissues of teeth, and periodontium under chewing loading.

Key words: parodontium, splinting fiber, basalt, fiberglass, teeth, mobility. 